\title{
THE EFFECT OF MUSCLE DAMAGE AND THE IL-6-174C/G POLYMORPHISM ON THE SERUM IL-6 LEVELS OF OLDER MEN
}

\author{
O EFEITO DO DANO MUSCULAREDO POLIMORFISMO IL-6-174C/G NOS NIVEIS SÉRICOS DE \\ IL-6DEHOMENS IDOSOS
}

\author{
EL EFECTO DEL DAÑO MUSCULARY DEL POLIMORFISMO IL-6-174C/G EN LOS NIVELES SÉRICOS DE \\ IL-6ENHOMBRES ANCIANOS
}

Leonardo Costa Pereira' (Physical Education Professional)

Marileusa Dosolina Chiarello? (Pharmacist)

Kerolyn Ramos Garcia (Public Health Specialist)

Alessandro de Oliveira Silva ${ }^{3}$ (Physical Education Professional)

Paulo Henrique Fernandes do Santos ${ }^{3}$

(Nurse)

Silvana Schwerz Funghetto' (Nurse)

Jonato Prestes ${ }^{4}$

(Physical Education Professional)

Margô Gomes de Oliveira

Karnikowski

(Pharmacist)

1. Universidade de Brasília (UnB), Brasília, DF, Brazil.

2. Centro Universitário Euro Americano (UniEURO), Brasília, DF, Brazil.

3. Centro Universitário de Brasília (UniCEUB), Brasília, DF, Brazil.

4. Universidade Católica de Brasília (UCB), Brasília, DF, Brazil.

\section{Correspondence:}

Leonardo Costa Pereira. Unieuro, Asa Sul, SCE/SUL Trecho 0, Conjunto 5No S/N, Brasília,

Brazil. 70310-500

leonardo.pcllcp@gmail.com.

\begin{abstract}
Introduction: Fast population aging is a global reality. Today's major challenge is to promote the healthy aging of more and more people by acting on factors that can be modified, such as physical exercise. Regular exercise could contribute to the prevention of chronic diseases associated with aging. Research has been conducted on the physical training response of elderly individuals, but there is not yet any consensus on the influence of strength training or IL-6 polymorphism on levels of inflammatory markers such as IL-6 and muscle damage marker CK, particularly in healthy elderly male individuals. Objectives: The aim of this study was to evaluate the relationship of IL-6 promoter -174 C/G gene polymorphism on systemic IL-6 responses and muscle damage after eccentric strength training in elderly men. Methods: This is a prospective, high-quality study. Gene frequency of polymorphism of promoter gene IL6 G-174C was identified using the Hardy-Weinberg test in 28 older male volunteers. The relationships of each genotype with IL-6 and CK serum levels were analyzed. CK and IL-6 levels were determined at pre-training and $0 \mathrm{~h}, 3 \mathrm{~h}, 24 \mathrm{~h}$, and $48 \mathrm{~h}$ post-training periods. Results: Differences in baseline and post-training IL-6 levels of genotypic groups were observed for all time periods analyzed $(p=0.029)$. Eccentric exercise efficiently reduced post-intervention muscle damage, thus showing a statistical difference between the pre- and post-intervention time points $(p=<0.0005)$. Conclusion: Eccentric training influenced CK and IL-6 modulation independently of the polymorphism of the IL-6 promoter gene-174 C/G. Level of evidence Il, Prospective comparative type.
\end{abstract}

Keywords: Elderly; Strength Training; Inflammation.

\section{RESUMO}

Introdução: O rápido envelhecimento populacional é uma realidade global. O principal desafio atual épromover o envelhecimento saudável de cada vez mais pessoas, atuando em fatores que podem ser modificados, como por exemplo, o exercício físico. O exercício regular pode contribuir com a prevenção de doenças crônicas associadas ao envelhecimento. Pesquisas foram realizadas quanto às respostas dos idosos ao treinamento físico, mas ainda não há nenhum consenso sobre a influência do treinamento de força ou do polimorfismo da lL-6 sobre os níveis dos marcadores inflamatórios como a IL-6 e a creatina quinase (CK) como marcadores do dano muscular, principalmente, em homens saudáveis e idosos. Objetivos: O objetivo do presente estudo consistia em avaliar a relação do polimorfismo do gene promotor IL-6-174 C/G sobre as respostas sistêmicas de IL-6 e danos musculares após o treinamento de força excêntrica em homens idosos. Métodos: Trata-se de um estudo prospectivo de alta qualidade. A frequência de polimorfismo do gene promotor IL6 G-174C foi identificada ao utilizar o teste de Hardy-Weinberg em 28 homens idosos voluntários. As relações de cada genótipo com os níveis séricos de IL-6 e CK foram analisadas. Os níveis de CK e IL-6 foram determinados no pré-treinamento e 0h, 3h, 24h e 48h pós-treinamento. Resultados: Foram observadas diferenças nos níveis de ll 6 basais e pós -treinamento dos grupos genotípicos em todos os períodos analisados ( $p=0,029$ ). O exercício excêntrico reduziu eficientemente os danos musculares pós-intervenção, apresentando uma diferença estatística entre os pontos de tempo pré e pós-intervenção ( $p=<0,0005)$. Conclusão: O treinamento excêntrico influenciou a modulação de CK elL-6 independentemente do polimorfismo do gene promotor IL-6-174 C/G. Nível de evidência Il, Estudo prospectivo comparativo.

Descritores: Idoso; Treinamento de resistência; Inflamação.

\section{RESUMEN}

Introducción: El rápido envejecimiento poblacional es una realidad global. El principal desafío actual es promover el envejecimiento saludable de cada vez más personas, actuando en factores que pueden ser modificados, como por ejemplo, el ejercicio físico. El ejercicio regular puede contribuir con la prevención de enfermedades crónicas asociadas al envejecimiento. Fueron realizadas investigaciones sobre las respuestas de los ancianos al entrenamiento físico, pero aún no hay consenso sobre la influencia del entrenamiento de fuerza o del polimorfismo de ll-6 sobre los 
niveles de los marcadores inflamatorios, como IL-6y la creatina quinasa (CK) como marcadores del daño muscular, principalmente en hombres saludables y ancianos. Objetivos: El objetivo del presente estudio consistía en evaluar la relación del polimorfismo del gen promotor IL-6-174 C/G sobre las respuestas sistémicas de IL-6 y daños musculares después de entrenamiento de fuerza excéntrica en hombres ancianos. Métodos: Se trata de un estudio prospectivo de alta calidad. La frecuencia de polimorfismo del gen promotor IL6 G-174C fue identificada al utilizar el test de HardyWeinberg en 28 hombres ancianos voluntarios. Se analizaron las relaciones de cada genotipo con los niveles séricos de IL-6y CK. Los niveles de CKell-6 fueron determinados en pre entrenamiento y $0 \mathrm{~h}, 3 \mathrm{~h}, 24 \mathrm{~h}$ y $48 \mathrm{~h}$ post entrenamiento. Resultados: Se observaron diferencias en los niveles de IL 6 basales y post entrenamiento de los grupos genotípicos en todos los períodos analizados $(p=0,029$ ). El ejercicio excéntrico redujo eficientemente los daños musculares post intervención, presentando una diferencia estadística entre los puntos de tiempo prey post intervención $(p=<0,0005)$. Conclusión: El entrenamiento excéntrico influenció la modulación de CKell-6independientemente del polimorfismo del gen promotor IL-6-174 C/G. Nivel de evidencia II - Estudio prospectivo comparativo.

Descriptores: Anciano; Entrenamiento de Resistencia; Inflamación.

\section{INTRODUCTION}

The level of autonomy and the maintenance of elderly's independence are dependent on functional capacity preservation, which is influenced by aging process typical alterations, like skeletal muscle functions and inflammatory response.'

The regular practice of physical exercises throughout the life cycle has been increasingly stimulated as a strategy for achieving healthy aging, ${ }^{2,3}$ generating questions about which protocols and modalities of physical exercises should be prescribed for elderly individuals. In this matter, the different inflammatory responses arising accordingly to the type, intensity, volume and frequency of training and the specificities of each gender ${ }^{4}$ should be considered.

Eccentric exercise is an important resource in the recovery and prevention of musculoskeletal system injury ${ }^{5,6}$ due to the strengthening of muscle and connective tissue, as well as neural adaptations. ${ }^{8}$

Adaptations generated by eccentric training should be appropriate to different people. The decrease on number and size of muscle fibers, especially of type II, seems to be the major reason for age reduced muscle mass. Therefore, physiological changes such as dehydration, mitochondrial dysfunction, inflammation ${ }^{9}$ of muscle tissue, hormonal alterations, metabolic disorders, decreased oxygen consumption, loss of mobility and muscle function, increased muscle fatigue and skeletal fractures, as well as higher risk of falls can be observed. ${ }^{10}$

The regular practice of exercises by elderly could contribute to prevention of systemic inflammation markers increases and non-transmissible chronic processes associated with aging progression., ${ }^{211}$ However, the studies are controversial and results about inflammatory markers vary according to training protocol used. . $^{12,13}$

There is no consensus on the influence of strength training on inflammatory markers concentrations such as IL-6, nor on the influence of IL-6 polymorphism on these markers and muscle damage in healthy elderly individuals, especially for the male population. 5.12,13

Among the main mediators of senile inflammation, IL-6 plays a central role in the inflammatory process and in the negative prognosis of some aging associated diseases, especially in sedentary individuals. ${ }^{14,10}$

However, serum levels of IL-6 also change during and after physical exercise of different modalities and intensities. When IL-6 is produced by muscles following physical exercise stimulus, it seems to play a beneficial role to the body and also helps muscle recovery through satellite cells activation. ${ }^{6,11-13}$

The literature is controversial regarding the relation of the IL-6 polymorphism with the serum increases of this protein after training, of resistance or not. Some studies indicate association between the polymorphism
- 174C / G and the increase of the serum IL-6 after training session. ${ }^{14}$ On the other hand, there are studies that did not identify this association.

The aim of the present work was to evaluate the relations of the IL-6 promoter -174 C / G gene polymorphism on systemic IL-6 responses and muscle damage after eccentric strength training in elderly men.

\section{METHODS}

The present research, of experimental and quantitative nature, was carried out with older human subjects accordingly to fundamental ethical requirements of Resolution CNS 510/16, including Catholic University of Brasilia Research Ethics Committee approval (UCB/CEP 272-10 report). Independent variables were the high damage eccentric training model and the IL-6 promoter -174 C / G gene polymorphism, and dependent variables were IL-6 and creatine kinase (CK) plasma concentrations, body composition, isometric and eccentric strength and plasmatic lipid profile.

Elderly subjects, aged from 66 to 75 years old, were invited to participate in the study through an explanatory speech, after what they read and signed the informed consent form. To determine the level of physical activity, the International Physical Activity Questionnaire (IPAQ), full version, was applied. The initial sample consisted of 46 male subjects, 60 years of age or older and physically active.

Individuals with changes in pressure levels $(n=3)$, cardiovascular or pulmonary disease manifestations $(n=2)$ and orthopedic alterations, under beta blockers treatment $(n=6)$, and those who did not fulfill the health status examination ( $N=3$ ) were excluded from the sample, totaling 14 exclusions before the trials. Those who did not accomplished all blood sample collections during the trials $(n=4)$ were also excluded. The final sample was constituted by 28 individuals.

Electrical bioimpedance tests for evaluating participants'body composition were carried out on the BIA Biodynamics model $310^{\circ}$, software version 6and manufacturer's recommendations were followed.

Muscle strength was assessed by Biodex System ${ }^{\oplus} 4$ Pro isokinetic dynamometer (Biodex Medical Systems Inc., USA). The muscle group evaluated was that of knee extensors of the dominant limb. The participants were oriented and trained for the specific knee extension movement, when the dynamometer support arm moved down (speed toward $=45 \% / \mathrm{s}$ ) and when it moved up ( speed Away $=120 \% / \mathrm{s}$ ). The arm only exerted resistance in the downward displacement, what generated an active eccentric force. The range of motion of the knee joint was previously collected by a CARCI manual goniometer, limiting extension by $135^{\circ}$ and flexion by $90^{\circ}$.

Twenty-four hours before the training, the participants were familiarized with the equipment by performing two sets of seven repetitions 
with a 120-second interval between sets, and 24 hours after the familiarization, the training was performed with 10 sets of seven repetitions with Interval of 120 seconds between sets, in which the initial phase was knee extension and the final was knee flexion. The participants were positioned on the equipment according to the manufacturer's instructions and protocol was adapted from Willoughby, VanEnk \& Taylor. ${ }^{15}$

Participant blood samples were collected at five different time periods: before the eccentric training sessions and at 0h, 3h, 24h and 48 hours after their end. Five $\mathrm{mL}$ of blood samples were collected by a qualified professional under hygienic conditions and transferred to sealable tubes, immediately refrigerated and transported to the analyzing laboratory, where the tubes were centrifuged and then aliquoted to the different analysis.

Serum concentrations of IL-6 inflammatory mediator before and after the intervention were determined by the enzyme-linked immunosorbent assays method. ${ }^{16}$ The samples were processed in duplicate and calibration curve points in triplicate. Creatine kinase (CK) serum concentrations were determined by kinetic-spectrophotometric methodology. The threshold value for CK, indicating muscle damage, was 155U/L.6,7 Serum lipid profiles, including total cholesterol - COLt and fractions were measured in the AutoHumalyzer apparatus manufactured by Human - GMBH (Germany).

Total genomic DNA was obtained from whole blood samples as described in laboratory manuals using the QIAGEN KIT. The frequency of the $C / G$ alleles was determined by the polymerase chain reaction technique (PCR-RFLP). Finally, amplification of the promoter region 174 and genomic sequencing with Big Dye was performed..$^{10}$

Statistical analysis comprised Hardy-Weinberg equilibrium determined by $x 2$ test to compare observed and expected genotypic frequency. Continuous data were expressed as means \pm SD or simple means (with 95\% confidence interval), if applicable. Shapiro-Wilk tests were applied to verify the normal distribution of study variables. Repeated measures of ANOVA were used to compare the action of CK and IL-6 over the 48 hours post-training period. The sphericity component was checked by the Mauchley test. When the sphericity assumption was not found, the importance of the F-ratios was adjusted according to the Greenhouse-Geisser procedure. The Tukey Post-hoc test with the Bonferroni Arrangement was applied in the occurrence of importance. Comparisons of genotypic subtypes were made using the independent t-test. The areas under the curve (AUC) of CK and IL-6 were calculated between the points of $0 \mathrm{~h}$ and $48 \mathrm{~h}$. The level of significance was $\mathrm{p} \leq$ 0.05 and SPSS software version 20.0 (Somers, NY, USA) was used as a tool for statistical treatment.

\section{RESULTS}

Allelic and genotypic frequencies for the IL-6 GG and CC/CG polymorphism groups did not significantly differ according to Hardy-Weinberg test ( $x 2=3.11, p=0.078$ ). The major part of participants $(75 \%)$ were homozygotos for the G allele, followed by the heterozygotes (21\%) and the rare combination of the homozygosity of the C allele (4\%).

There was no significant difference between age, anthropometric measurements or lipid profile for IL-6 genotypes. (Table 1)

To determine genotype-phenotype correlations, serum CK and IL-6 levels were compared between groups. (Table 2) There was no significant difference between the baseline, peak and area under the curve (AUC) of the serum CK concentrations in relation to genotype groups.

The training intervention caused statistically significant changes in the serum concentration of CK over time $(p<0.0005)$. (Figure 1) Eccentric training increased the serum CK levels from $149.1 \pm 98,0 \mathrm{U} / \mathrm{l}$ on pre-workout to $234.0 \pm 106.2 \mathrm{U} /$ in $24 \mathrm{~h}$ post-training period.
Significant differences between the groups were found for IL-6 serum concentrations (table 2), once the GG baseline was higher than the GC/CC group ( $p=0.016)$. In response to exercise, the GG group had significantly higher IL-6 serum peak $(p=0.041)$ and AUC $(p=0.029)$ than CC/CG group.

Due to these differences, IL-6 genotype kinetics were analyzed. (Figure 2) The eccentric exercise intervention did not lead to any statistically significant changes in IL-6 concentration over time for the GG group ( $p=0.632)$, and the GC and CC ( $p=0.305)$. IL-6 concentrations were significantly higher $(p<0.05)$ for the $G G$ group during all time period measures.

There was no significant difference between the mean baseline strength of the 10-series training related to the genotype groups. From the fifth set's, the participants strength was significantly smaller than the first set's $(p \leq 0.05)$.

Table 1. Physical characteristics for subjects and genotypes (mean \pm SD).

\begin{tabular}{c|c|c|c}
\hline & GG & CC/CG & p-value \\
\hline Age (year) & $70.7 \pm 4.0$ & $71.6 \pm 4.0$ & 0.627 \\
\hline Stature $(\mathrm{cm})$ & $166 \pm 7.2$ & $166 \pm 2.6$ & 0.960 \\
\hline Weight $(\mathrm{kg})$ & $72.9 \pm 13.2$ & $78.7 \pm 8.5$ & 0.284 \\
\hline \%FAT & $27.0 \pm 5.4$ & $30.8+2.8$ & 0.088 \\
\hline Lean body mass (kg) & $52.7 \pm 7.6$ & 54.35 .6 & 0.619 \\
\hline BMl $\left(\mathrm{kg} / \mathrm{m}^{2}\right)$ & $26.3 \pm 4.0$ & $28.6 \pm 3.6$ & 0.201 \\
\hline Cholesterol $(\mathrm{mg} / \mathrm{dl})$ & $206 \pm 56$ & $202 \pm 42$ & 0.887 \\
\hline HDL $(\mathrm{mg} / \mathrm{dl})$ & $42 \pm 10$ & $37 \pm 8$ & 0.298 \\
\hline LDL $(\mathrm{mg} / \mathrm{dl})$ & $136 \pm 45$ & $122 \pm 32$ & 0.497 \\
\hline VLDL $(\mathrm{mg} / \mathrm{dl})$ & $31 \pm 12$ & $43 \pm 22$ & 0.229 \\
\hline Triglycerides (mg/dl) & $151 \pm 58$ & $212 \pm 111$ & 0.207 \\
\hline
\end{tabular}

Legend: BMI - Body Mass Index. *Significantly different in between GG and CC/CG group, $p \leq 0,05$.

Table 2. Activity of Creatine kinase (CK) and content of interleukin 6 (IL-6) for IL6 genotypes groups in baseline, peak and area under the curve (AUC) during $48 \mathrm{~h}$.

\begin{tabular}{c|c|c|c}
\hline & GG & CC/CG & p-value \\
\hline CK $(U / \mathrm{l})$ & & & \\
\hline BaseLine & $164.5(115.3-213.7)$ & $102.9(74.6-131.1)$ & 0.249 \\
\hline Peak & $262.7(212.2-313.2)$ & $217.0(142.8-291.2)$ & 0.326 \\
\hline AUC/h & $200.4(161.7-239.1)$ & $179.0(123.8-235.6)$ & 0.559 \\
\hline IL-6 (pg/ml) & & & \\
\hline BaseLine & $4.61(2.97-6.25)$ & $1.56(0.01-3.28)$ & 0.016 \\
\hline Peak & $7.97(4.20-11.74)$ & $2.87(1.41-4.32)$ & 0.041 \\
\hline AUC/h & $5.50(3.22-7.78)$ & $1.64(0.52-2.77)$ & 0.029 \\
\hline
\end{tabular}

Legend: AUC - Area Under the Curve. *Significantly different in between GG and CC/CG group, $p \leq 0,05$.

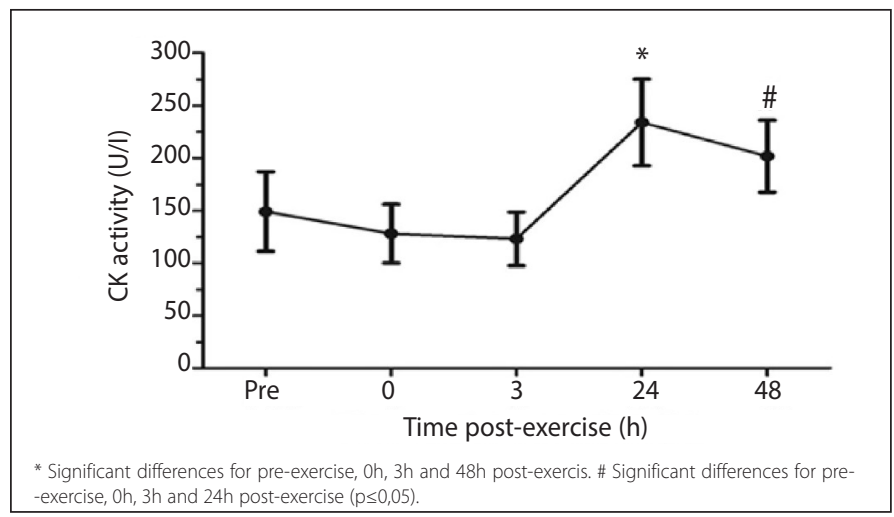

Figure 1. Creatine quinase (CK) activity in response to eccentric exercise for the stu population show. 


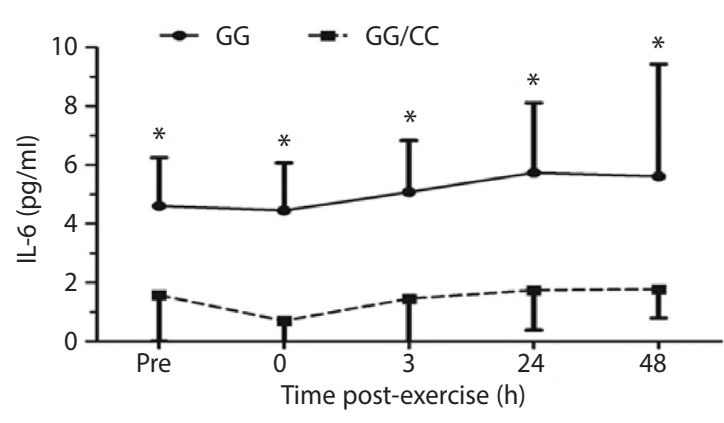

* Significant differences for GC/CC group ( $p \leq 0,05)$.

Figure 2. Interleukin 6 (IL-6) activity in response to excentric exercise for GG and GC/CC genotypes gorups.

\section{DISCUSSION}

Physical training has been stimulated to contrast sedentary lifestyle for all age groups and has generated a wide discussion about selected protocols, especially those involving resistance. In this study with older person, eccentric training with seven repetitions of ten series was investigated, and strength declining magnitude for the dominant limb in knee extension was observed. In fact, after five repetition series a significant decline in strength ( $p=0.008$ ) was already observed, indicating that exhaustion was reached. This result helps to define the number of series to be settled in a training trial of seven repetitions for elderly, a fact not described in some studies with similar methodology. ${ }^{4}$

Participants were found to have body fat percentage above levels recommended by the American College of Sports Medicine. Ethnology of aging body fat increase content in not yet totally understood, but some studies found a strong relationship of fat accumulation with daily life activities (DLAs) decrease and nutritional transition, affecting all age groups. ${ }^{1,17}$ High prevalence of excess body fat is a relevant factor, since it is directly related to many chronic diseases, including diabetes and cardiovascular diseases, among others ${ }^{1,18}$. It should be noted that, in this context, inflammatory markers play important roles and increased levels of these molecules, such as IL-6 have been widely related to chronic disease process. ${ }^{1,2,12,13,19}$ Distinct physical activity practices may modify the negative effects associated with chronic disease evolution, provided that they are performed in a safety and efficiency way. ${ }^{20}$

Eccentric training intervention was used in this study because its therapeutic benefits are well described in available literature..$^{10,13}$ However, its action on inflammatory response is still controversial, especially in the elderly. ${ }^{19}$ The intensity and duration of eccentric muscle activity may induce muscle damage, leading to muscular hypertrophy that can be monitored by the serum levels of CK. ${ }^{8,9}$ In this study, CK serum levels reached maximum values (234.0 \pm 106.2 $\mathrm{U} / \mathrm{I}$ ) after 24 hours of training activity, demonstrating that eccentric training was efficient to induce muscle damage, since the threshold for men muscle damage is $155 \mathrm{U} / \mathrm{L}$.

In this study, as in other studies, 7,20 the elevation of CK activity throughout the experiment was observed. However, peak values for CK diverge from other timeline surveys.? This study was limited to verify CK values up to 48 hours after eccentric training, so it is observed that, although not significant, there was a tendency to decrease CK levels in 48h, when compared to $24 \mathrm{~h}$, but not enough to reach the values of baseline.
The muscle damage evidenced by CKelevation in the present study may indicate an evolution of the elderly body's homeostasis state to an inflammatory condition, as already found in other studies. ${ }^{21} \mathrm{IL}-6$ is mentioned in the literature as "exercise factor", exerting a signaling role of metabolic pathways involved in physical exercise in several training methodologies, in different age groups and gender. ${ }^{22}$ However, research results on this inflammatory marker changes after eccentric training with elderly male subjects is not so far reported. A significant increase of IL-6 levels from 3 hours to 48 hours $(p=0.029)$ after eccentric training was observed. The physiological function of IL-6 in response to eccentric training may be related to the effects of this cytokine on induction of proliferation of satellite cells precursor of new myotubes, which play an import role on muscle regeneration and hypertrophy. ${ }^{2,23,24}$ In addition, IL-6 can stimulate, via intracellular calcium, the adaptive response of skeletal muscle tissue to exercises. ${ }^{10}$ In addition, it was observed that the kinetics of CK increase after three hours of the eccentric training was followed by the IL-6 kinetics increase, demonstrating that the levels of this cytokine followed the muscle damage for the studied population.

After analysis of the genotypes, it was observed that the polymorphism of the IL- 6 promoter $-174 \mathrm{G} / \mathrm{C}$ gene is related to IL- 6 levels, but not to the pre-intervention and post-training CK serum concentration. The polymorphism of the IL-6 promoter -174 G/C gene showed great influence on the serum levels of IL-6 inflammatory marker ( $p=0.016)$. A greater allelic frequency of $\mathrm{G}$ and a higher genotypic frequency of $\mathrm{G}$ homozygote were observed, corroborating literature findings. 5,6,12,21,25

The presence of the $C$ allele was determinant for lower serum levels of IL-6 basal moment ( $p=0.016$ ) as well as for IL-6 serum levels throughout the trials time periods ( $p=0.029$ ).

Result corroborates other research groups' works, ${ }^{14}$ indicating that G homozygous population has higher IL-6 serum levels, being more propitious to diseases related to higher levels of this marker. ${ }^{14}$

Both the modulatory effects of eccentric training and the influence of IL-6 cytokine level require further clarification. However, because IL-6 is a multifunctional cytokine, it plays an important role in metabolic signaling 8,21

Indeed, independently of the genotype imposed by the IL-6 promoter region and the IL-6 serum concentration level, one can benefit from the positive effects of eccentric training in the muscle mass rehabilitation context. ${ }^{2}$

However, the $\mathrm{G}$ homozygous group, which has significantly higher basal serum levels $(p=0.016)$, requires more attention in order to elucidate the effects of serum concentrations of IL-6 on the human body, especially in the elderly.

\section{CONCLUSIONS}

IL-6 serum levels increased with muscle damage in elderly men submitted to eccentric physical training. However, this increase did not happen at the same intensity on different genotypic groups of promoter region of the gene-174 C / L IL-6 polymorphism. It seems to be a relation of elderly IL-6 serum levels increases and the homozygous genotype $G$ allele, even before the intervention proposed in this work.

\section{ACKNOWLEDGMENT}

CAPES, which was the funding agency for this study.

All authors declare no potential conflict of interest related to this article

AUTHORS' CONTRIBUTIONS: Each author made significant individual contributions to this manuscript. LCP (0000-0003-3319-5679)*: Substantial contribution in the conception, design of the work, analysis, data interpretation, and writing of the work; MDC (0000-0002-4985-6681)*: analysis and interpretation of data for the work; KRG (0000-0003-2464-6255)* data interpretation and writing of the work, review; AOS (0000-0003-3513-7034)*: design of the work and review; PHFS (0000-0003-4533-0129)*: writing, review, and intellectua concept; SSF (0000-0002-9332-9029)*: writing and intellectual concept; JP (0000-0003-0399-8817)*: statistical analysis, intellectual concept, and creation of the training protocols and research project; MGOK (0000-0002-5662-2058)*: writing, intellectual concept, and creation of the entire research project. ${ }^{*} \mathrm{ORCID}(\mathrm{Open}$ Researcher and Contributor ID). 


\section{REFERENCES}

1. Kaminsky LA, Bonzheim KA, Garber C, et al. ACSM's Resource Manual for Guidelines for Exercise Testing and Prescription. Maltimore: Lippincott Williams \& Wilkins; 2006.

2. Berthold HK, Laudes M, Krone W, Gouni-Berthold I. Association between the interleukin-6 promoter polymorphism -174G/C and serum lipoprotein(a) concentrations in humans. PLoS One. 2011;6(9).

3. Scarabottolo CC, Garcia Júnior JR, Gobbo LA, Alves MJ, Ferreira AD, Zanuto EAC, Oliveira WGA, et al. Influence of physical exercise on the functional capacity in institutionalized elderly. Rev Bras Med do Esporte. 2017;23(3):200-3.

4. Choi SJ, Lim JY, Nibaldi EG, Phillips EM, Frontera WR, Fielding RA, et al. Eccentric contraction-induced injury to type I, Ila, and Ila/IIx muscle fibers of elderly adults. Age (Dordr). 2012;34(1):215-26.

5. Baumert P, Lake MJ, Stewart CE, Drust B, Erskine RM. Genetic variation and exercise-induced muscle damage: implications for athletic performance, injury and ageing. Eur J Appl Physiol. 2016;116(9):1595-625.

6. Silva FOC, Macedo DV. Exercício físico, processo inflamatório e adaptação: uma visão geral. Rev Bras Cineantropom Desempenho Hum. 2011;13(4):320-8

7. Passaglia DG, Emed LGM, Barberato SH, Guerios ST, Moser Al, Silva MMF, et al. Efeitos agudos do exercício físico prolongado: avaliação após ultramaratona de 24 horas. Arq Bras Cardiol. 2013;100(1):21-8.

8. Wu CT, Hsieh CC, Lin CC, Chen WC, Hong JH, Chen MF. Significance of IL-6 in the transition of hormone-resistant prostate cancer and the induction of myeloid-derived suppressor cells. J Mol Med. 2012;90(11):1343-55.

9. Willoughby DS, Vanenk C, Taylor L. Effect of concentric and eccentric contraction exercise-induced on muscle injury, inflammation and serum IL-6. J Exerc Physiol. 2003;6(4):8-15.

10. Vardiman JP, Moodie N, Siedlik JA, Kudrna RA, Graham Z, Gallagher P. Short-Wave Diathermy Pretreatment and Inflammatory Myokine Response After High-Intensity Eccentric Exercise. J Athl Train. 2015;50(6):612-20

11. Silva EDFR, Junior FLES, Souza JC, Silva Júnior FL, Oliveira RJ, Pereira LC, et al. Imunosenescência e exercício físico. Educ Física em Rev. 2010;4(3):1-11.

12. Correa CS, Baroni BM, Radaelli R, Lanferdini FJ, Cunha GS, Reischak-Oliveira Á, et al. Effects of strength training and detraining on knee extensor strength, muscle volume and muscle quality in elderly women. Age (Dordr). 2013;35(5):1899-904.

13. Eynon N, Ruiz JR, MeckelY, Santiago C, Fiuza-Luces C, Gómez-Gallego F, et al. Is the -174 C/G polymorphism of the $/ L 6$ gene associated with elite power performance? A replication study with two different Caucasian cohorts. Exp Physiol. 2011;96(2):156-62.

14. Kaufman E, Hall S, Surova Y, Widner H, Hansson O, Lindqvist D. Proinflammatory Cytokines Are Elevated in Serum of Patients with Multiple System Atrophy. PLoS One. 2013;8(4):e62354.

15. Tajra V, Tibana RA, Vieira DCL, Farias DL, Teixeira TG, Funghetto SS, et al. Identification of high responders for interleukin- 6 and creatine kinase following acute eccentric resistance exercise in elderly obese women. J Sci Med Sport. 2014;17(6):662-6.

16. Olomolaiye O, Wood NAP, Bidwell JL. A novel Nlalll polymorphism in the human IL-6 promoter. Eur . Immunogenet. 1998;25(2-3):267.

17. Serrano AL, Baeza-Raja B, Perdiguero E, Jardí M, Muñoz-Cánoves P. Interleukin-6 Is an Essential Regulator of Satellite Cell-Mediated Skeletal Muscle Hypertrophy. Cell Metab. 2008;7(1):33-44.

18. Pereira DS, Garcia DM, Narciso FMS, Santos JMD, Dias BZ, Quieroz ER, et al. Effects of -174 G/C polymorphism in the promoter region of the interleukin- 6 gene on plasma IL- 6 levels and muscle strength in elderly women. Brazilian J Med Biol Res. 2011;44(2):123-9.

19. Neme IB, Alessandro LSN, Brenzikofer R, Macedo DV. Time course of muscle damage and inflammatory responses to resistance training with eccentric overload in trained individuals. Mediators Inflamm. 2013:2013:204942.

20. Willoughby DS, Vanenk C, Taylor L. Effect of concentric and eccentric contraction exercise-induced on muscle injury, inflammation and serum IL-6. J Exerc Physiol. 2003;6(4):8-15.

21. Harris TB, Ferrucci L, Tracy RP, Corti MC, Whacholder S, Ettinger WH, et al. Associations of elevated Interleukin-6 and C-Reactive protein levels with mortality in the elderly. Am J Med. 1999;106(5):506-12.

22. Passaglia DG, Emed LGM, Barberato SH, Guerios ST, Moser Al, Silva MMF, et al. Efeitos agudos do exercício físico prolongado: avaliação após ultramaratona de 24 horas. Arq Bras Cardiol. 2013;100(1):21-8.

23. Yamin C, Duarte JAR, Oliveira JMF, Amir O, Sagiv M, Eynon N, et al. IL6 (-174) and TNFA (-308) promoter polymorphisms are associated with systemic creatine kinase response to eccentric exercise. Eur J App Physiol. 2008;104(3):579-86

24. van de Vyver M, Myburgh KH. Cytokine and satellite cell responses to muscle damage: Interpretation and possible confounding factors in human studies. J Muscle Res Cell Motil. 2012;33(3-4):177-85.

25. Wu CT, Hsieh CC, Lin CC, Chen WC, Hong JH, Chen MF. Significance of IL-6 in the transition of hormoneresistant prostate cancer and the induction of myeloid-derived suppressor cells. J Mol Med (Berl). 2012;90(11):1343-55. 